\title{
PENGEMBANGAN INSTRUMEN BAKU KECERDASAN JAMAK ANAK USIA DINI
}

\author{
Martini Jamaris \\ Fakultas Ilmu Pendidikan, Universitas Negeri Jakarta
}

\begin{abstract}
This reasearch was done in the form of research and development. The reason underlied the selection of the reasearch method was because the purpose of the reseacrh was to develop a valid and realiable instrument which can be used to measure the multiple-intellegences of the 4-5 years old childen. The multiple-intelligences measured were consisted of eigth dimensions, there were: verbal/linguistic intelligence, logical mathematical intelligence, visual spatial intelligence, intrapersonal intelligence, interpersonal intelligence, bodily/kinesthetic intellgence, music/rythmic intelligence and naturalist intelligence. Based on the need in researching and developing, therefore, the study was conducted in two faces, as folowed: (1) the first face was literature research aiming to analyzed and synthesis concepts, principles, and theories. The result of the literature study was used formulte the construct of multiple intelligences, especially for the 4-5 years old children; (2) the second face was to define and to develop the valid and reliable multiple intelligences instrument for the 4-5 years old children.
\end{abstract}

Key Words : Research and Development, Multiple Intelligences, The valid and realible instrument, The 45 years old chlidren, Literature Research, Define and Develop

\begin{abstract}
Abstrak
Penelitian ini dilakukan dengan metode research and Development. Alasan pemilihan metode tersebut karena tujuan penelitian ini adalah mengembangkan validitas dan reliabilitas suatu instrumen yang bisa digunakan untuk mengukur kecerdasan majemuk anak usia 4-5 tahun. Kecerdasan majemuk dikur dengan delapan dimensi, yaitu: kecerdasan bahasa/verbal, kecerdasan logika matematika, kecerdasan visual, kecerdasan intrapersonal, kecerdasan interpersonal, kecerdasan gerak/kinestetik, kecerdasan musik, dan kecerdasan natural. Berdasarkan penelitian dan pengembangan, oleh karena itu, penelitian ini dilaksanakan dalam dua tahap, yaitu: (1) tahap pertama adalah penelitian literatur yang bertujuan untuk menganalisis dan mensintesis konsep, prinsip, dan teori. Hasil dari penelitian literatur digunakannnya rumus untuk mengkonstruksi kecerdasan majemuk. Khususnya anak usia 4-5 tahum, (2) tahap kedua yaitu mendefinisikan dan mengembangkan validitas dan reliabiltas instrumen kecerdasan majemuk untuk anak usia 4-5 tahun.
\end{abstract}

Kata Kunci: penelitian dan pengembangan, kecerdasan majemuk, instrumen validitas dan reliabilitas, anak usia 4-5 tahun, penelitian literatur, mendefinisikan dan mengembangkan

\section{PENDAHULUAN}

Anak usia dini merupakan makhluk Tuhan yang memiliki berbagai potensi baik secara fisiologis, kognitif, psikososial, bahasa dan komunikasi. Menurut Gardner (1993: xii-xiii) berbagai potensi perkembangan manusia, termasuk anak usia dini, dapat ditampilkan dalam bentuk multiple intelligences atau kecerdasan jamak. Kecerdasan ini terdiri dari 8 (delapan) bentuk kecerdasan yaitu logical mathematics intelligence (kecerdasan logika matematika), verbal/linguistic intelligence (kecerdasan verbal/linguisitik), visual spatial inelligence (kecerdasan visual spatial), bodily kinesthetic intelligence (kecerdasan koordinasi gerakan 
tubuh), interpersonal intelligence (kecerdasan interpersonal) intrapersonal intelligence (kecerdasan intrapersonal) rytmic-musical intelligence (kecerdasan musik dan irama) dan naturalist intelligence (kecerdasan naturalist). Kecerdasan jamak merupakan kemampuan yang berkembang dari hasil interaksi anak usia dini dan lingkungan di sekitarnya.

Hasil penelitian yang dilakukan oleh Martini Jamaris (2005:16-17) tentang pengembangan kecerdasan jamak terhadap 36 anak usia 3-5 tahun yang berasal dari kalangan sosial ekonomi rendah menunjukkan bahwa stimulasi dan intervensi kecerdasan jamak dapat meningkatkan kecerdasan jamak anak yang bersangkutan. Selanjutnya hasil penelitian Martini Jamaris pada tahun 2012 tentang profil kecerdasan jamak anak usia 4-5 tahun di DKI Jakarta telah menghasilkan profil kecerdasan jamak anak usia 4-5 tahun walaupun secara khusus instrumen tersebut belum dapat menemukan anak yang memiliki kecerdasan jamak yang bersifat ekstrim, arti yang sangat menonjol atau sangat tinggi atau yang sangat rendah ( Martini Jamaris dan kawan-kawan, 2012: 9697). Hal ini disebabkan oleh jumlah peserta penelitian yang terbatas. Oleh sebab itu perlu dilakukan penelitian lanjutan, khususnya yang berkaitan dengan pengembangan instrumen baku yang digunakan untuk mengukur kecerdasan jamak anak usia 4-5 tahun yang bersifat komprehensif, artinya dapat menemukan anak yang memiliki kecerdasan jamak yang normal, di bawah normal atau di atas normal.

Pengembangan kecerdasan jamak merupakan salah satu cara untuk mempersiapkan anak di masa usia dini agar memiliki fondasi yang kuat dalam perkembanganya di masa datang. Dengan demikian mereka dapat menjadi generasi penerus bangsa seperti yang diharapkan yaitu generasi yang cerdas, kreatif dan memiliki nilai-nilai moral dan agama yang kuat.

Permasalahan yang dapat
diidentifikasi berkaitan pengembangan insrrumen maku kecerdasan jamak adalah: (1) bagaimana menemu-kenali kecerdasan jamak pada anak usia dini, khususnya anak usia 4-5 tahun?, (2) konsepkonsep, prinsip-prinsip dan teori-teori apa sajakah yang dapat digunakan untuk menemu kenali dan menganalisis perkembangan kecerdasan jamak anak usia dini, khususnya anak usia 4-5 tahun ? (3) bagaimanakah mengembangkan instrumen baku yang dapat digunakan untuk mengukur kecerdasan jamak anak usia dini, khususnya anak usia 45 tahun sehingga analisis perkembangan kecerdasan jamak anak tersebut dapat dilakukan secara akurat dan dapat dijadikan dasar untuk mengambil berbagai tindakan yang sesuai dengan kebutuhan perkembangan anak?

Penelitian ini termasuk ke dalam kategori penelitian dan pengembangan ilmu pengetahuan dan teknologi di bidang pendidikan dan pengembangan anak usia dini. Khususnya yang berkiatan dengan kecerdasan jamak anak usia 4-5 tahun. Dengan demikian penelitian ini bermanfaat untuk (1) pengembangan khasanah teoritis dan praktis di bidang pendidikan dan pengembangan anak usia dini, khususnya di bidang pengembangan instrumen baku kecerdasan jamak anak usia 4-5 tahun; (2) bagi peneliti lain hasil penelitian ini diharapkan dapat digunakan hasil untuk penelitian lanjutan yang lebih mendalam sehingga memperoleh temuan-temuan yang lebih komprehensif tentang kecerdasan jamak anak usia 4-5 tahun.

\section{Hakikat Kecerdasan Jamak (Multiple Intelligences)}




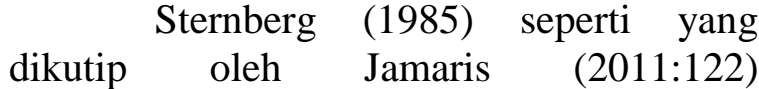
mengemukakan bahwa kecerdasan atau inteligensi merupakan aktivitas mental yang di arahkan pada kegiatan yang bertujuan untuk menyesuaikan diri, memilih dan membentuk lingkungan yang sesuai dengan kehidupan individu. Selanjutnya Papalia \& Old (1986:237) menegaskan bahwa inteligensi adalah hasil interaksi aktif antara kemampuan yang dibawa sejak lahir dengan berbagai pengalaman yang diperoleh dari lingkungan yang menghasilkan kemampuan individu untuk mengingat, mengerti makna dari konsep kongkrit dan konsep abstrak, memahami hubungan-hubungan antara objek, peristiwa, dan ide serta kemampuan dalam menerapkan kesemua hal tersebut untuk memecahkan berbabagai masalah yang dihadapi. Selanjutnya Gardner (1993:67-68) menyatakan bahwa kecerdas-an bukanlah merupakan sesuatu yang bersifat tunggal akan tetapi bersifat lebih dari satu kecerdasan. Ia menyebutnya dengan multiple intelligences atau kecerdasan jamak.

Kecerdasan jamak (multiple intelligences) merupakan temuan dan terobosan baru di dalam bidang inteligensi yang ditemukan oleh Howard Gardner (1993:xii-xiii) yang juga dikutip oleh Jamaris (2011: 80). Beberapa alasan yang dikemukan oleh Gardner tentang temuannya tersebut di antaranya adalah isolasi potensial oleh kerusakan otak. Berdasarkan penelitian yang dilakukan oleh Gardner cs. ditemukan bahwa seseorang yang mengalami kecelakaan dan ternyata ada pengaruhnya terhadap otaknya. Misalnya, seseorang yang rusak 'bagian' depan otaknya, maka kecerdasan linguistiknya rusak, sehingga ia sukar berbicara, membaca, dan menulis, namun ia masih bisa melakukan berbagai kegiatan lainnya, seperti matematika, menyanyi menari, dan berhubungan dengan orang lain. Hal ini didukung oleh Li (1996, dalam
Martini Jamaris, 2013:99) yang mengemukakan bahwa apabila otak memiliki peta khusus yang berkaitan dengan fungsi kognitif atau kemampuan berpikir maka apabila terjadi kelainan pada otak yang memiliki fungsi tersebut maka kemampuan yang berkaitan dengan fungsi otak tersebut akan tergangu. Gardner menyimpulkan bahwa ada paling tidak tujuh daerah yang otonom dalam sistem otak dan masingmasing mempengaruhi satu macam kecerdasan dan mempengaruhi keberadaan anak 'super'. Dengan demikian, jika ada satu peringkat kecerdasan yang sangat tinggi pada seseorang maka membuat orang itu lemah dalam beberapa kecerdasan lainnya. Misalnya, seseorang yang tinggi logikamatematikanya, lemah dalam berkomunikasi, dan fungsi berbahasa.

Alasan selanjutnya adalah adanya fakta sejarah yang menunjukkan bahwa perkembangan kecerdasan jamak ditunjang oleh hasil penelitian yang menemukan bahwa sejak zaman dahulu manusia telah menggunakan kecerdasan jamak. Hal ini dapat dilihat dari gambar-gambar di gua-gua kuno (Bronowski, 1986:204). Selain alasan tersebut di atas temuan psikometrik menunjang keberadaan kecerdasan jamak. Hal ini dapat dilihat dari materi yang menggali informasi dan kosa kata di dalam tes baku IQ. Berbagai temuan penelitian yang berkaitan dengan psikologi eksperimental yang mengemukakan bahwa seseorang yang memiliki kemampuan khusus dalam membaca belum tentu dapat mentransfer kemampuan tersebut ke dalam logika matematika. dengan baik. Selain hal tersebut terdapat operasi inti atau seperangkat operasi masing-masing inteligensi, seperti pada kecerdasan musik, kecerdasan ini ditunjang oleh kepekaan dalam membedakan berbagai struktur irama (Ross, Marshal, Scott, 1999:11). Selanjutnya kecerdasan dalam menggkoordinasi gerak motorik 
(bodily kinesthetic), ditunjang oleh kemampuan meniru gerakan tubuh orang lain, kemampuan membangun rutinitas gerakan motorik halus. Lazaer (2000:7) mengemukakan bahwa kecerdasan jamak (multiple Intelligences) merupakan perkembangan mutakhir dalam bidang intelligensi yang menjelaskan hal-hal yang berkaitan dengan jalur-jalur yang digunakan oleh manusia untuk menjadi cerdas dan ia menambahkan satu kecerdasan lagi dalam kecerdasan jamak yaitu kecerdasan natralist.

Setiap kecerdasan pada anak usia dini muncul pada saat tertentu sesuai irama perkembangannya. Piaget (1971: 49:91, 1985: 60) mengemukakan bahwa kecerdasan kognitif merentang dari fase sensorimotor (0-2 tahun), fase praoperasional (2-7 tahun), fase operasi kongkrit (7-12 tahun) dan fase operasi formal (12 sampai usia dewasa. Demikian pula kecerdasan-kecerdasan yang lainnya.

\section{Delapan Jenis Kecerdasan Jamak}

Gardner (1983:73-237) menjelaskan tujuh jenis kecerdasan jamak (multiple inteligencies ) dan Lazaer memperkaya temuan Gardner dengan nemambahkan satu jenis kecerdasan lain yaitu kecerdasan naturalist (2000:25) yang diuraikan dalam bagian berikut ini.

\section{Kecerdasan Verbal/Linguistik}

Bagian dari multiple intelligence berkaitan dengan kepekaan terhadap bunyi, struktur, makna dan fungsi kata serta bahasa yang muncul melalui kegiatan bercakapcakap, berdiskusi dan membaca. Selanjutnya kecerdasan jamak muncul pula dalam bentuk kemampuan dalam menggunakan kata-kata secara efektif, secara lisan atau tulisan, termasuk kemampuan untuk memanipulasi sintaks atau struktur bahasa, fonologi atau bunyi dalam bahasa, semantik atau pemaknaan bahasa, dan dimensi pragmatik atau penggunaan secara praktis bahasa ( Gardner, 1993 :76 -79, Pohl, 2000: 49, Fograty, 1991 :67). Di antara penggunaannya termasuk retorik (mempengaruhi orang lain untuk bertindak), mnemonik (menggunakan bahasa untuk mengingat informasi), menjelaskan (menggunakan bahasa untuk menjelaskan), dan metabahasa (menggunakan bahasa untuk membahasnya sendiri). Ciri-ciri yang dapat diidentifikasi dari kemunculan kecerdasan ini adalah: senang bercakap-cakap, senang membaca, menulis, bercerita, bermain games kata-kata dsbnya

Perkembangan kecerdasan verbal/lingustik anak usia 4-5 tahun sejalan dengan perkembangan verbal/linguistik anak yang bersangkutan . Martini Jamaris (2005: 182) mengemukakan pendapat Papalia \& Olds (1995: 222, Paplia \&Olds, 1985 : 420) bahwa anak usia 4-5 tahun telah melewati masa penguasaaan bahasa secara reseptif yaitu kemampuan untuk mnedengar dan merekam bunyi bahasa. Yang didengar. Mereka telah berada dalam tahap penguasaan bahasa secara ekspresif. Artinya telah mampu menggunakan bahasa untuk berkomunikasi dan untuk menyatakan keinginan atau penolakan, serta bercakapcakap. Anak usia 4-5 tahun telah mengusai sedikitnya 2500 kosa kata yang mencakup bentuk, warna, bentuk dan warna. Oleh sebab itu, ia dapat menjadi pendengar yang baik dan dapat pula berpartisipasi secara aktif dalam suatu percakapan.

Bertitik tolak dari perkembangan kemampuan verbal/linguistik anak usia 4-5 tahun maka kecerdasan verbal/linguisitk anak usia 4-5 tahun dapat diidentifikasi dari kemampuanya dalam penguasaan kosa kata dan mampu menggunakannya secara aktif dalam berbagai kegiatan berkomunikasi. Dampak dari kemampuan ini dapat dilihat dari kesukaan anak dalam: (a) suka bercakap-cakap (b) menuturkan atau mengarang lelucon atau cerita sederhana dan 
pendek, (c) sangat hafal nama, tempat, tanggal atau hal-hal kecil, (d) menikmati membaca buku di waktu senggang, (e) mengeja kata-kata dengan mudah dan tepat, (f) menyukai pantun, puisi yang lucu dan permainan kata, (g) menikmati dan mendengar kata-kata lisan, ceritera, dan radio, (h) unggul dalam pelajaran membaca dan menulis.

\section{Kecerdasan Logika Matematika}

Bagian dari multiple intelligences berkaitan dengan kepekaan dalam mencari dan menemukan pola yang digunakan untuk melakukan kalkulasi hitung dan berpikir abstrak serta berpikir logis dan berpikir ilmiah. Kemunculan kecerdasan ini dapat dilihat dari kemampuan menemukan perbedaan pola-pola logika dan numerik, kemampuan melakukan argumentasi yang panjang teratur dengan pola pikir yang terstruktur secara logis dan ilmiah. Jenis proses yang digunakan dalam pemecahan logika matematika termasuk : kategorisasi, klasifikasi, inferensi, generalisasi, kalkulasi dan tes hipotesis (Gardner, 1993:157-159, Pohl, 2000:49, Fograty, 1991 :67) Sejalan dengan perkembangan kemampuan berpikir atau kemampuan kognitif anak usia 4-5 tahun yang berada dalam fase pra operasional (Piaget, 1974:49-91) maka kecerdasan logika matematika anak yang bersangkutan mencakup kemampuan untuk mengidentifikasi dan mengingat objek, peristiwa, dan orang yang telah dikenalnya sebelumnya, selanjutnya menghadirkan kesemua hal tersebut di dalam pikirannya, mulai memahami prinsip konsevasi yaitu perubahan yang menyangkut berat, ukuran, dan jumlah, memahami konsep bilangan ada angka, mampu mengubungkan dan membandingkan objek, peristiwa dan orangorang berdasarkan hubungan sebab akibat atau berdasarkan ukuran, bentuk dan jumlah, mampu mengelompokkan objek, peristiwa dan orang sesuai dengan klasifikasinya, memahami simbol-simbol tertentu mengandung arti dan makna (Papalia \&Olds 1995:212-224, Papalia \& Olds 1985: 420).

Berdasarkan hal tersebut di atas maka anak usia 4-5 tahun yang memiliki kecerdasan logika matematika dapat diidentifikasi dari: (a) dapat menghitung di luar kepala secara cepat sesuai dengan tingkat perkembangannya, (b) dapat memberikan penjelasan secara logis atau rasional,(c) sering bertanya bertanya, mengapa ini, itu dll (d) suka melakukan berbagai eksperimen, (e) dapat menyusun benda peristiwa, dan orang sesuai dengan klasifikasi dan kategori, (f) dapat menyusun benda peristiwa, dan orang sesuai dengan hierarchinya, (g) mudah memahami hubungan sebab akibat.

\section{Kecerdasan Visual-Spatial}

Bagian dari multiple intellegences yang berkaitan dengan kepekaan dalam memadukan kegiatan persepsi visual (mata) maupun pikiran serta kemampuan mentransformasikan persepsi visual spatial seperti yang dilakukan dalam kegiatan melukis, mendesain pola, merancang bangunan, dll (Gardner, 1993: 174-175, Pohl,2000:46, Fograty,191:67). Glass \& Holyoak (1986: 140) menjelaskan bahwa viualspatial adalah kemampuan yang berkaitan dengan memadukan ciri-ciri objek atay benda yang ada di dalam lingkungan sekitar dalam bentuk gambaran mental yang dapat diungkapkan kembali dalam bentuk informasi rinci, gambar, lukisan, atau pahatan, dll). Kecerdasan ini melibatkan kepekaan terhadap warna, garis, bentuk, ukuran, luas, dan hubungan-hubungannya yang ada di antara unsur-unsur itu.

Perkembangan kecerdasan visual spatial anak usia 4-5 tahun berkembang sejalan dengan kemampuan dalam kepekaan memadukan kegiatan persepsi visual (apa yang dilihat) dengan kemampuan kognitif 
atau kemampuan berpikir dan mentransformasikan kedua hal tersebut ke dalam berbagai bentuk, warna, ukuran dan hubungan-hubungan yang ada dan hubungan-hubungan yang mungkin ada di antara semua hal tersebut. Di dalamnya termasuk kemampuan memvisualisasikan, dan secara grafis menggambarkan ide-ide visual dan spasial, serta secara tepat mengorientasikan diri sendiri ke dalam matriks spasial (Martini Jamaris, 2005: 188).

Bertitik tolak dari uraian tersebut maka anak usia 4-5 tahun yang memiliki kecerdasan visual-spatial yang tinggi dapat diidentifikasi dari: (a) dapat menggambarkan ide-ide visual dalam bentuk gambar, (b) dapat memberikan gambaran jelas tentang hal/peristiwa, (c ) dapat menggambar sosok orang atau hewan sesuai dengan baik, (d) dapat menyusun pazzel dengan tepat, (e) dapat menyusun balok untuk membangun konstruksi tiga dimensi., (f) mudah memahami gambar dan ilustrasi yang ditampilkan.

\section{Kecerdasan Bodily-Kinesthetic (Koor- dinasi Gerakkan Tubuh-Motorik)}

Bagian dari multiple intelligences

yang berkaitan dengan kepekaan dan keterampilan dalam mengontrol koordinasi gerakan tubuh melalui gerakan motorik kasar dan halus, seperti menggunakan alat-alat secara terampil, melompat, berlari, berhenti secara tiba-tiba dengan terampil dalam rangka melakukan gerakan senam atau gerakan menari, silat, dll. Kecerdasan ini juga mencakup keterampilan tubuh khusus seperti koordinasi, keseimbangan, kekuatan, fleksibiltas, kecepatan, taktil dan kemampuan haptik (Gardner,1993:2006-212, Pohl, 2000: 49, Fograty, 1991: 67). Perkembangan kecerdasan dalam mengkoordinasikan gerakkan tubuh dan motorik sejalan dengan perkembangan gross motor dan fine motor dan menmadukan gerakkan otot kasar dan otot halus dengan koordinasi yang seimbang.

Kepheart (1973 : 15-17) yang dikemukakan oleh Martini Jamaris (2009:107-107) menjelaskan bahwa perkembangan kemampuan mengkordinasikan gerakan tubuh dan motorik terdiri dari empat dimensi: (1) posture yaitu kemamuan mengkoordinasikan persepsi visual dan persepsi motorik secara tepat sehingga individu dapat memposisikan tubuhnya di antara objek-objek di sekitarnya, (2) laterality yaitu kemampuan dalam menggerakkan otot kasar dan halus sesuai dengan arah yang dituju, (3) perpaduan posture dan laterality merupakan prasyarat dalam melakukan koordinasi gerakkan tubuh dan otot atau motorik, baik gerakkan tubuh yang melibatkan otot kasar, seperti berjalan, melompat, berlari, menarik, mendorong, dll, dan gerakkan tangan dan jari-jari tangan yang melibatkan koordinasi otot halus, seperti menulis, meronce, memahat, melukid, dll. Menurut Seefeldt \& Babaour (1994) seperti yang dikemukakan oleh Martini Jamaris (2003: 47) menyatakan bahwa anak usia 4-5 tahun telah mampu melakukan koordinasi gerakkan tubuh dan motorik kasar dan halus secara seimbang. Di bidang gerakan tubuh yang melibatkan otor kasar. Dengan demikian kecerdasan dalam koordinasi gerakan tubuh dan motorik yang tinggi pada usia ini 4-5 tahun dapat diidentifikasi dari kemampuan anak dalam (a) mengendarai sepeda roda tiga atau roda dua, (b) berlari dan berhenti dengan sempurna, (c) memanjat, menaiki tangga, (d) melompat dengan satu kaki atau dua kaki, (e) meloncat jauh,(f) berdiri secara seimbang dengan satu kaki, (g) dapat meniti jembatan atau berjalan di atas balok secara seimbang. Di bidang gerakan otot halus, anak seusia ini sudah dapat: (a) menggunakan gunting untuk memotong kerta, (b) memasang dan 
membuka tali sepatu, kancing atau resluiting baju, (c) menahan kertas dengan satu tangan sementara tangan yang lain digunakan untuk menulis, atau kegiatan yang lain, (d) meronce manik-manik, (e) melipat kertas untuk dijadikan suatu bentuk, (f) memasukkan benang ke dalam jarum, dll.

Pada tahap yang lebih jauh.kemampuan ini terwujud dalam kemampuan menggunakan keseluruhan potensi tubuh untuk mengekspresikan ide-ide dan perasaan (misalnya, sebagai aktor, pantomim, sebagai atlit, atau penari, dll), kemampuan untuk menggunakan tangan untuk memproduksikan atau mentransformasikan sesuatu/benda (misalnya, sebagai pemahat, pelukis, mekanik, ahli bedah).

\section{Kecerdasan Intrapersonal}

Bagian dari multiple intelegences yang berkaitan dengan kepekaan dalam melakukan instrospeksi terhadap diri sendiri dan membandingkannya dengan kelemahan dan kekuatan orang lain. Kecerdasan ini termasuk memiliki gambaran akurat tentang diri sendiri (kekuatan sendiri dan keterbatasan sendiri), kesadaran tentang perasaan dalam diri, intensi, motivasi, temperamen dan keinginan-keinginan; dan kemampuan untuk disiplin diri sendiri, pemahaman sendiri dan percaya diri. (Gardner,1993: 237-249, Pohl, 2000:49, Fograty, 1991:67).

Kecerdasan intrapersonal anak usia 4-5 tahun berkembang sejalan dengan perkembangan kemampuannya dalam mengenal dirinya. Sejalan dengan hal ini, Santrock (1996: 378) mengemukakan bahwa kecerdasan intra personal berkaitan dengan pemahaman individu terhadap dirinya, yang ditampilkan dalam bentuk self concept atau konsep diri yang mencakup identitas diri, perbedaan dirinya dengan orang lain. Selanjutnya, Erikson (Woolfolk \& McCuneNicolich, 1984: 84 dan Martini Jamatris, 2011: 42-43) menjelaskan bahwa anak usia
4-5 tahun berada dalam fase perkembangan psikososial yang berfokus pada insiatif diri, artinya anak mampu melakukan berbagai aktivitas berdasarkan kehendaknya sendiri atau inisiatifnya. Oleh sebab itu, ciri-ciri kecerdasan intrapersonal anak usia 4-5 tahun dapat diidentifikasi dari : (a) kemampuan dalam dapat memusatkan perhatiannya untuk melakukan berbagai kegiatan, terutama kegiatan yang dilakukan berdasarkan inisiatifnya, (b) menunjukkan sikap bebas dan memiliki pandangan sendiri, (c) memiliki kemauan yang kuat, (d) mampu belajar dan bekerja sendiri, (e) mengekspresikan pikiran dan perasaan dengan tepat, (f) dapat mengarahkan kegiatan dalam mencapai tujuan yang diharapkan, dan memiliki hobi

\section{Kecerdasan Interpersonal}

Bagian dari multiple intelligences yang berkaitan dengan kepekaan dalam membedakan dan merespon perilaku yang ditampilkan orang lain. Kemunculan dari kecerdasan ini dapat dilihat kemampuan menggerakkan dan berkomunikasi dengan orang lain, bekerja sama dalam tim, disenangi oleh orang-orang lain yang berada disekitarnya, kemampuan meng-gerakkan dan berkomunikasi dengan orang lain, bekerja sama dalam tim, disenangi oleh orang-orang lain yang berada disekitarnya (Gardner, 1993: 237-249, Pohl, 2000: 49, Fograty, 1991: 67) . Selanjutnya kecerdasan ini juga menyangkut kemampuan mempersepsikan dan membedakan berbagai modus, maksud tertentu, motivasi, dan perasaan dari orang-orang lain. Di dalam kecerdasan ini termasuk kepekaan ekspresi muka, suara, dan gerak-gerik, kemampuan untuk membedakan hal-hal dari banyak jenis tanda-tanda interpersonal, kemampuan untuk bereaksi secara efektif terhadap tandatanda demikian secara pragmatik (misalnya 
mempengaruhi sekelompok orang untuk ikut dengannya dalam suatu tindakan).

Perkembangan kecerdasan interpersonal anak usia 4-5 tahun berkembang sejalan dengan perkembangan psikososialnya. Sefeelt dan Barbaour seperti yang dikutipoleh Martini Jamaris (2005: 182) mengemukakan bahwa pada usia ini anak sudah dapat berkomunikasi dengan orang lain yang diwujudkan dalam mengikat persabatan, bekerja sama dalamn kelompok, menolong sesama, dapat mengendalikan emosi, mematuh disiplin memahami nilainilai baik dan tidak baik.

Berdasarkan hal tersebut maka kecerdasan interpersonal anak usia 4-5 tahun dapat diidentifikasi dari: (a) punya teman, (b) banyak bersosialisasi di sekolah dan lingkungannya,(c) tampak sangat mengenali lingkungannya, (d) terlibat dalam kegiatan kelompok di sekolah atau di luar sekolah, (d) mampu berperan sebagai penengah pada teman-teman atau keluarga jika ada konflik, (c) menikmati permainan kelompok,(d) menunjukan empati terhadap perasaan orang lain, (e) dapat menjadi penasihat atau pemecah masalah di antara teman-temannya, (f) menikmati kegiatan mengajar orang lain, (g) menunjukkan bakat untuk menjadi pemimpin.

\section{Kecerdasan Musik-Ritmik}

Bagian dari multiple intellegences

yang berkaitan dengan kepekaan dalam mendengarkan suara, musik, dan suara lainnya ( Gardner, 104-105, Pohl, 2000: 49) Perkembangan kecerdasan musik -ritmik anak usia 4-5 tahun merupakan akibat perpaduan perkembangan anak di bidang fisiologis, kognitif, psikososial, bahasa dan komunikasi ( Martini Jamaris, 2005: 183) . Selanjutnya, anak usia 4-5 tahun sudah dapat menghayatikarya seni. Oleh sebab itu anak usia 4-5 tahun sudah dapat mengekpresikan kecerdasan musik-ritmik melalui berbagai aktivitas yang musik dan ritme. Kecerdasan musik-ritmik anak usia 4-5 tahun dapat diidentifikasi dari: (a) mudah dalam mengingat irama dari suatu melodi, (b) dapat bergerak sesuai dengan irama lagu atau musik yang didengar, (c) mudah mengikuti irama lagu atau musik, (d) senang memainkan alat musik, (e) mencipta-kan musik-ritmik seperti mengeluarkan senandung hasil ciptaannya sendiri, (f) suka mendengarkan/menikmati suara musikritmik.

\section{Kecerdasan Naturalist}

Bagian dari multiple intelligences yang berkaitan dengan kepekaan dalam mengapresiasi alam dan lingkungan sekitar. Sejalan dengan perkembangan musik-ritmik, kecerdasan naturalist anak usia 4-5 tahun merupakan akibat perpaduan perkembangan anak di bidang fisiologis, kognitif, psikososial, bahasa dan komunikasi. Kemunculan kecerdasan ini dapat dilihat dari kecintaan terhadap alam dan lingkungan melalui berbagai kegiatan seperti kepedulian terhadap lingkungan atau konservasi lingkungan alam sekitar (Lazaer, 2000:73, Pohl, 2000:49). Oleh sebab itu kecerdasan naturalist anak usia 4-5 tahun dapat diidentifikasi melalui : (a) senang melakukan kegiatan konservasi lingkungan, seperti memelihara tanaman, hewan, (b) menunjukkan kesadaran ekologi yang baik, seperti menjaga kelestarian lingkungan sekitar, (c) peka terhadap berbagai gejala alam, (d) senang melakukan observasi alam sekitar, seperti berjalan-jalan mengamati alam di lingkungan sekitar.

\section{Konstruk/Sintesis}

Teori-Teori Kecerdasan Jamak Anak Usia 4-5 Tahun Bertitik tolak dari hasil penelitian literatur tersebut di atas maka dapat dirumuskan konstruk atau sistesis kecerdasan jamak, khususnya kecerdasan jamak anak 
usia 4-5 tahun sebagai berikut: 4-5 tahun kemampuan berpikir yang terdiri dari dimensi kecerdasan atau kemampuan berpikir yang terdiri dari : (1) kecerdasan verbal/linguistik aitu kemampuan dalam penguasaan kosa kata dan mampu menggunakannya secara aktif dalam berbagai kegiatan berkomunikasi yang mencakup kemampuan anak dalam: (a) suka bercakapcakap, (b) menuturkan atau mengarang lelucan atau cerita, (c) sangat hafal nama, tempat, tanggal atau hal-hal kecil, (d) menikmati membaca buku di waktu senggang, (e) mengeja kata-kata dengan mudah dan tepat, (f) menyukai pantun, puisi yang lucu dan permainan kata, (g) menikmati dan mendengar kata-kata lisan, ceritera, dan radio, (h) unggul dalam pelajaran membaca dan menulis; (2) kecerdasan logika matematika yaitu kepekaan dalam mencari dan menemukan pola yang digunakan untuk melakukan kalkulasi hitung dan berpikir abstrak serta berpikir logis dan berpikir ilmiah, yang mencakup kemampuan anak dalam: (a) dapat menghitung di luar kepala secara cepat sesuai dengan tingkat perkembangannya untuk anak usia 4-5 tahun dapat menghitung dari 1-10. (b) dapat memberikan penjelasan secara logis atau rasional,(c) sering bertanya bertanya, mengapa ini, itu dll (d) suka melakukan berbagai eksperimen, (e) dapat menyusun benda peristiwa, dan orang sesuai dengan kategori, (f) dapat menyusun benda peristiwa, dan orang sesuai dengan hierarchinya, (g) mudah memahami hubungan sebab akibat; (3) kecerdasan visual spatial adalah kepekaan dalam memadukan kegiatan persepsi visual (mata) maupun pikiran serta kemampuan mentransformasikan persepsi visual spatial seperti yang dilakukan dalam kegiatan melukis, mendesain pola, merancang bangunan, kecerdasan ini melibatkan kepekaan terhadap warna, garis, bentuk, ukuran, luas, dan hubungan-hubungannya yang ada di aatara unsur-unsur itu dalam bentuk kemampuan dalam: (a) dapat menggambarkan ide-ide visual dalam dalam bentuk gambar, (b) memberikan gambaran jelas tentang hal/peristiwa, (c) menggambar sosok orang atau hewan yang sesuai dengan baik, (d) menyusun pazzel dengan tepat, (e) menyusun balok untuk membangun konstruksi tiga dimensi, (f) mudah memahami gambar dan ilustrasi yang ditampilkan, (4) kecerdasan dalam mengkordinasi gerak motorik adalah kepekaan dan keterampilan dalam mengontrol koordinasi gerakan tubuh melalui gerakan motorik kasar dan halus, posture yaitu kemampuan mengkoordinasikan persepsi visual dan persepsi motorik secara tepat sehingga individu dapat memposisikan tubuhnya di antara objekobjek di sekitarnya, laterality yaitu kemampuan dalam menggerakkan otot kasar dan halus sesuai dengan arah yang dituju, perpaduan posture dan laterality merupakan prasyarat dalam melakukan koordinasi gerakkan tubuh dan otot atau motorik, baik otot kasar maupun otot halus yang mencakup: (a) mengendarai sepeda roda tiga atau roda dua, (b) berlari dan berhenti dengan sempurna, (c) memanjat, menaiki tangga, (d) melompat dengan satu kaki atau dua kaki, (e) meloncat jauh, (f) berdiri secara seimbang dengan satu kaki, (g) dapat meniti jembatan atau berjalan di atas balok secara seimbang, di bidang gerakan otot halus, anak seusia ini sudah dapat : (a) menggunakan gunting untuk memotong kerta, (b) memasang dan membuka tali sepatu, kancing atau resluiting baju, (c) menahan kertas dengan satu tangan sementara tangan yang lain digunakan untuk menulis, atau kegiatan yang lain, (d) meronce manik-manik, (e) melipat kertas untuk dijadikan suatu bentuk, (f) memasukkan benang ke dalam jarum; (5) kecerdasan intrapersonal adalah kemampuan 
dalam melakukan instrospeksi terhadap diri sendiri dan membandingkannya dengan kelemahan dan kekuatan orang lain, kecerdasan ini termasuk memiliki gambaran akurat tentang diri sendiri (kekuatan sendiri dan keterbatasan sendiri), kesadaran tentang perasaan dalam diri, intensi, motivasi, temperamen dan keinginan-keinginan; dan kemampuan untuk disiplin diri sendiri, pemahaman sendiri dan percaya diri yang mencakup: (a) kemampuan dalam dapat memusatkan perhatiannya untuk melakukan berbagai kegiatan, terutama kegiatan yang dilakukan berdasarkan inisitifnya, (b) menunjukkan sikap bebas dan memiliki pandangan sendiri, (c) memiliki kemauan yang kuat, (d) mampu belajar dan bekerja sendiri, (e) mengekspresikan pikiran dan perasaan dengan tepat, (f) dapat mengarahkan kegiatan dalam mencapai tujuan yang diharapkan, memiliki hobi, (6) kecerdasan interpersonal adalah kepekaan dalam membedakan dan merespon perilaku yang ditampilkan orang lain yang mencakup : (a) mempunyai teman yang banyak (lebih dari 3 orang) , (b) banyak bersosialisasi di sekolah dan lingkungannya,(c) tampak sangat mengenali lingkungannya, (d) terlibat dalam kegiatan kelompok di sekolah atau di diluar sekolah, (d) mampu berperan sebagai penengah pada teman-teman atau keluarga jika ada konflik, (c) menikmati permainan kelompok,(d) menunjukan empati terhadap perasaan orang lain, (e) dapat menjadi penasihat atau pemecah masalah diantara teman-temannya, (f) menikmati kgiatan mengajar orang lain, (g) menunjukkan bakat untuk menjadi pemimpin; (7) kecerdasan musik/ritmik adalah kemampuan dalam mendengarkan suara, musik, dan suara lainnya yang mencakup : (a) mudah dalam meningat irama dari suatu melodi, (b) dapat bergerak sesuai dengan irama lagu atau musik yang didengar, (c) mudah mengikuti irama lagu atau musik, (d) senang memainkan alat musik, (e) menciptakan musik-ritmik seperti mengeluarkan senandung hasil ciptaannya sendiri, (f) suka mendengarkan/ menikmati suara musikritmik; (8) kecerdasan naturalist kemampuan dalam mengapresiasi alam dan lingkungan sekitar yang mencakup : (a) senang melakukan kegiatan konservasi lingkungan, seperti memelihara tanaman, hewan, (b) menunjukkan kesadaran ekologi yang baik, seperti menjaga kelestarian lingkungan sekitar, (c) peka terhadap berbagai gejala alam, (d) senang melakukan observasi alam sekitar, seperti berjalan-jalan mengamati alam di lingkungan sekitar.

\section{Pengembangan Instrumen Baku Kecerdasan Jamak}

Instrumen baku kecerdasan jamak merupakan alat yang dibutuhkan dalam melakukan asesmen terhadap kecerdasan jamak. Dalam hal ini adalah kecerdasan jamak anak usia 4-5 tahun. Asesmen merupakan suatu kegiatan yang sistematis dalam rangka mengumpulkan informasi tentang perkembangan anak, termasuk perkembangan kecerdasan jamak anak usia 4-5 tahun. Martini Jamaris (2009: 58) mengemukakan bahwa dalam kegiatan assessmen terkandung kegiatan mengukur dan menilai. Mengukur (measurement) merupakan kegiatan yang dilakukan dengan menggunakan alat ukur seperti tes dan alat pengukur lainnya untuk mengetahui tingkat pencapaian keberhasilan individu setelah mengikuti suatu proses kegiatan tertentu (Woolfolk \& Nicolich, 1980: 506-507). Menilai adalah merupakan proses sistematik yang dilakukan dalam membandingkan data hasil pengukuran untuk mengambil keputusan (Gay, 1980:8).

Martni Jamaris (2009: 75-76) mengemukakan langkah-langkah pengembangan instrumen baku adalah sebagai berikut : 
a) Menganalisis teori-teori yang berkaitan dengan variabel yang akan diukur

b) Berdasarkan analisis teori-teori tersebut dirumuskan sintesis teori yang menjadi dasar dalam merumuskan konstruk dari variabel yang akan diukur

c) Berdasarkan konstruk tersebut dikembangkan dimensi dan indikator dari variabel yang akan diukur

d) Menetapkan besaran atau parameter yang bergerak dalam satu rentang kontinum dari satu kutub ke kutub lain yang berlawanan, seperti dari rendah ke tinggi, dari negatif ke positif, dari otoriter ke demokratis, dari dependen ke independen

e) Membuat kisi-kisi instrumen asessmen

f) Membuat konsep instrumen assessmen

g) Setelah konsep instrumen dianggap valid secara teoritis atau secara konseptual maka dilakukan pengadaan instrumen secara terbatas untuk diuji coba di lapangan

h) Uji coba instrumen di lapangan merupakan bagian dari proses validasi empiris. Dalam uji coba ini instrumen diberikan kepada sejumlah responden yang mempunyai karakteristik sama atau equivalen dengan karakteristik target populasi instrumen assessmen

i) Melakukan analisis data hasil uji coba instrumen yang bertujuan untuk mengetahui validitas instrumen. Pengujian validitas harus menggunakan kriteria internal, yaitu instrumen itu sendiri sebagi satu kesatuan yang dijadikan kriteria. Kriteria eksternal, yaitu kesesuaian hasil uji coba instrumen dengan hasil ukur instrumen tertentu yang sesuai dengan instrumen yang dibuat

j) Berdasarkan kriteria validitas instrumen diperoleh kesimpulan mengenai valid atau tidaknya butirbutir instrumen k) Bertitik tolak dari analisis butir maka butir-butir yang tidak valid dikeluarkan atau diperbaiki untuk di uji cobakan kembali, sedangkan butir yang valid dirakit kembali menjadi sebuah perangkat instrumen untuk melihat kembali validitas kontennya berdasarkan kisi-kisi instrumen

1) Selanjutnya dihitung koefisien reliabilitas instrumen dengan rentang 0 1 adalah besaran yang menunjukan besaran kualitas atau konsistensi hasil ukur instrumen. Semakin tinggi kooefisien reliabilitas makin tinggi pula kualitas instrumen tersebut. Batas koefiesien reliabilitas yang dianggap layak tergantung pada presisi yang dikehendaki oleh pengembang instrumen

m) Perakitan butir-butir instrumen yang valid untuk dijadikan instrumen final

\section{Validitas dan Reliabilitas Instrumen Asesmen Anak Usia Dini}

Instrumen asesmen kecerdasan jamak anak usia dini yang digunakan dalam mengukur dan menilai tingkat kecerdasan jamak anak usia dini, khususnya anak usia 45 tahun adalah instrumen asesmen yang memiliki tingkat validitas dan reliabilitas yang telah teruji. Instrumen asesmen dapat dikembangkan dalam bentuk tes, pedoman observasi, rating scale dan bentuk-bentuk lainnya yang dapat digunakan untuk memperoleh informasi tentang kecerdasan jamak anak usia dini.

Validitas instrumen kecerdasan jamak anak usia dini berkaitan dengan sejauh mana instrumen tersebut dapat mengukur apa yang harus diukur tentang kecerdasan jamak anak usia dini. Validitas instrumen yang perlu diperhatikan adalah content validity. Validitas ini menjadi dasar untuk menentkan sejauh mana ketepatan butir-butir instrumen berkorespondesi yang kecerdasan jamak 
anak usia dini. Reliabiltas instrmen kecerdasan jamak anak usia dini baru dapat diketahui setelah dilakukan berkali-kali dan memberikan hasil yang sama. Dengan demikian relaibilitas instrumen berkaitan dengan tingkat kepercayaan terhadap instrumen.

\section{Skema Dasar Pengembangan Instrumen}

\section{Baku Kecerdasan Jamak Anak Usia 4-5 Tahun}

Bertitik tolak dari skema dasar pengembangan instrumen yang dikemukakan oleh Martini Jamaris (2009: 77) maka dirumuskan skema dasar pengembangan instrumen baku kecerdasan jamak anak usia 4-5 tahun. Seperti yang digambarkan dalam diagram berikut ini.

Gambar 1. Skema Dasar Pengembangan Instrumen Baku Kecetdasan Jamak Anak Usia 4-5 Tahun

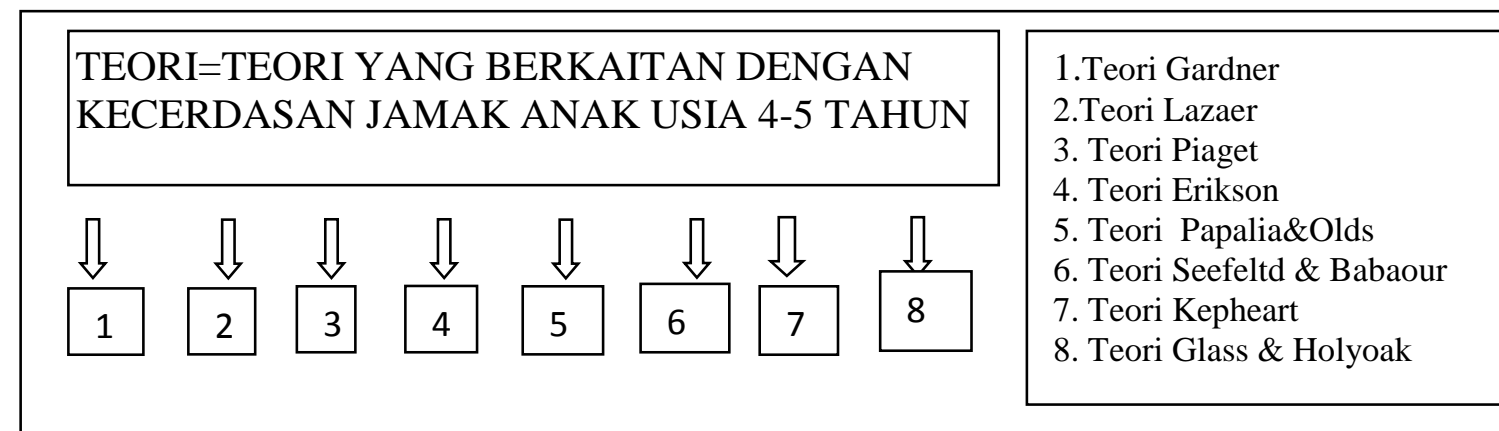

\

DEFINISI KONSEPTUAL : YANG DIAMBIL DARI SISNTESIS /KONSTRUK KECERDASAN JAMAK ANAK USIA 4-5 TAHUN

DEFINISI OPERASIONAL ADALAH BENTUKM OPERASIONAL DARI PENERAPAN DEFINISI KONSEPTUAL : SKOR YANG DIPEROLAH ANAK USIA 4-5 TAHUN SETELAH MELAKSANAKAN TES UNTUK PENGUKURAN KECERDASAN JAMAK

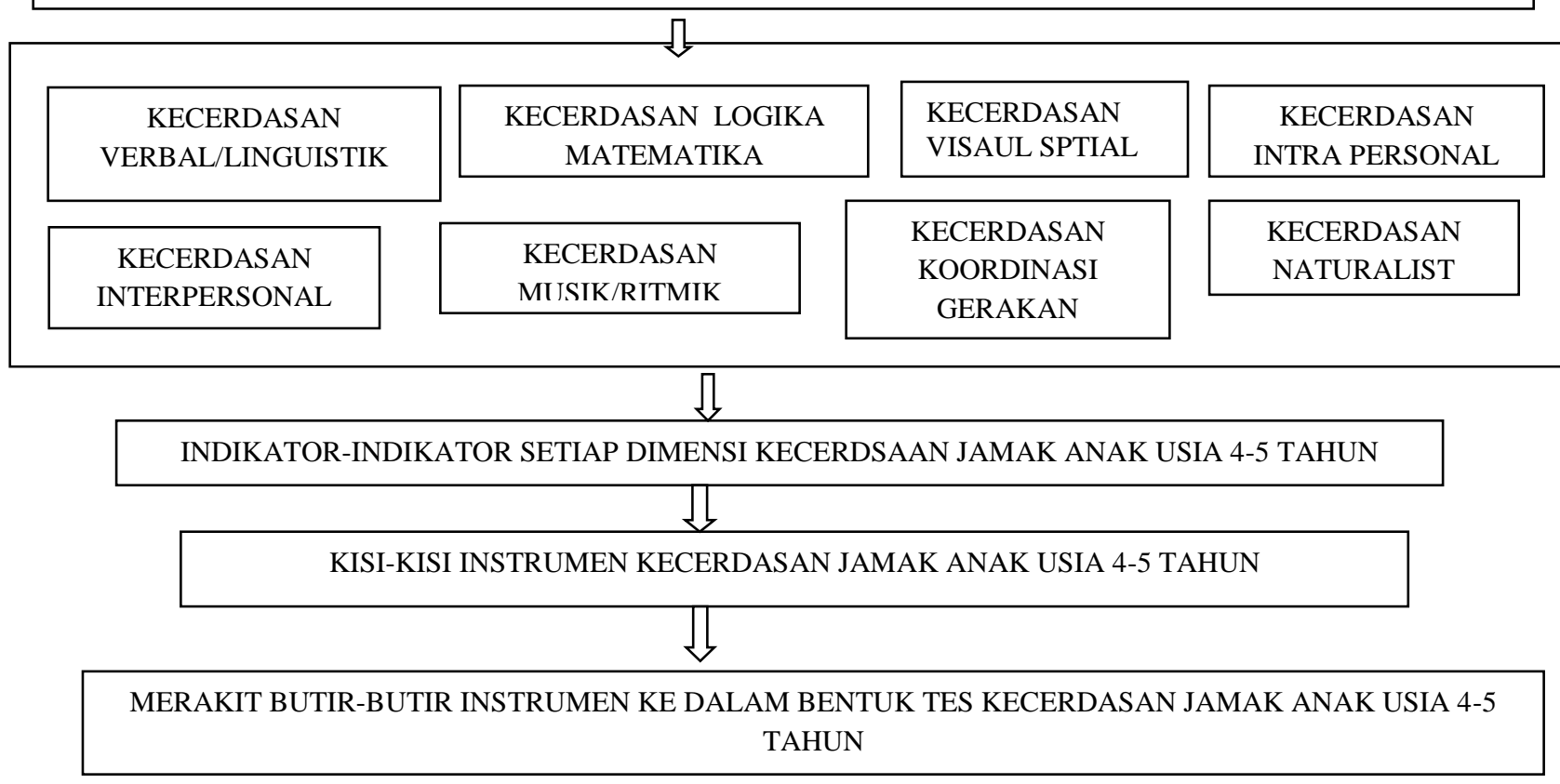


UJI COBA TES KECERDASAN JAMAK ANAK USIA 4-5 TAHUN UNTUK MENGETAHUI VALIDITAS DAN RELIABILITAS INSTRUMEN

\section{PENUTUP}

Kecerdasan jamak (multiple intelligences) merupakan aspek yang berperan dalam kesuksesan kehidupan manusia. Kecerdasan jamak merupakan integrasi dari berbagai kecerdasan berperan penting di dalam perkembangan manusia, termasuk anak usia dini. Kecerdasan ini terdiri dari 8 (delapan ) bentuk kecerdasan yaitu logical mathematics intelligence (kecerdasan logika matematika), verbal/linguistic intelligence (kecerdasan verbal/linguisitik), visual spatial inelligence ( kecerdasan visual spatial), bodily kinesthetic intelligence (kecerdasan koordinasi gerakan tubuh), interpersonal intelligence (kecerdasan interpersonal) intrapersonal intelligence (kecerdasan intrapersonal) rytmic-musical intelligence (kecerdasan musik dan irama) dan naturalist inteeligence (kecerdasan naturalist). Kecerdasan jamak merupakan kemampuan yang berkembang dari hasil interaksi anak usia dini dan lingkungan di sekitarnya.

Kecerdasan jamak sudah dapat diidentifikasi sejak anak berusia dini. Oleh sebab itu. disarankan untuk melakukan berbagai usaha untuk memahami kecerdasan jamak, khusus kecerdasan jamak anak usia dini yang berusia 4-5 tahun maka perlu dilakukan analisis teori-teori terkait dengan kecerdasan jamak yang dijadikan dasar untuk pengembangan instrumen baku kecerdasan jamak, khususnya untuk anak usia 4-5 tahun. Implikasi dari pengembang-an instrumen baku kecerdasan jamak, khususnya untuk anak usia 4-5 tahun adalah dengan mengukur kecerdasan jamak anak tersebut dengan instrumen baku mak dapat diberikan informasi yang signifikan tentang tingkat kecerdasan jamak anak usia 4-5 tahun. Selanjutnya dapat dijadikan dasar dalam menentukan berbagai tindakan yang efektif dalam menumbuh kembangkan anak usia dini, khususnya anak usia 4-5 tahun agar menjadi generasi penerus bangsa yang aktif, cerdas, kreatif dan mempunyai nilai agam dan moral yang tinggi

\section{DAFTAR PUSTAKA}

Glass, A. L., \& Holyoak, K. J. (1986). Cognition. London: McGraw-Hill Book Company

Woolfolk, A. E., \& Nicolich, L. M. (1984). Educational Psychology for Teachers. EnglewodCliff. New Jersey : Prentice Hall Inc

Seefeldt, C \& Barbaour, N. (1994). Early Childhood Education. New York: MacMillan Colege Publishing Company

Lazaer, D. (2000). Development of Multiple Intelligencies. New York: McMillan, Inc.

Papalia, D. E., \& Olds, S. W. (1995). Human Development. USA: McGraw-Hill Book Company . (1984). Psychology. USA: McGraw-Hill Book Company

Gardner, H. (1983). Frame of Mind: The theory of multiple intelligences. New York: Basic Bok

Piaget, J. (1972). The Realm of the Child. New York : Peacock 
(1985). The Equilibration of

Cognitive Structures. Chicago, IL: University of Chicago Press

Santrock, J. W. (1996). Child Development. Chicago: Brown \& Benchmark Publishers

Creswell, J. W. (2008). Educational Research: Planning, Constructing and Evaluating Quantitative and Qualtative Research. Columbus, Ohio: Upper Sadle River.

Kepheart (1976). Learning Disabilities. Chicago: Brown \& Benchmark Publishers

Kuebler R. R., \& Harry, S. J. (1980). Statistics. New York : John Wiley \& Sons, Inc. H. 170

Gay, L. R. (1980). Educational Evaluation and Measurament : Competencies for Analysis and Application. Columbus, Ohio : A Bell \& Howell Company.

Schmidt, L. Seven Time Smarter. (2001). New York : Three Rivers Press

Jamaris, M. (2011). Orientasi Baru Dalam Psikologi Pendidikan. Jakarta: Yayasan Penamas Murni. . (2009). Kesulitan Belajar: Perspektif, Asesmen dan Penanggulangannya. Jakarta : Yayasan Penamas Murni.

(2005). Pengembangan Multile Intelligences dan Aplikasinya
Melalui Pembelajaran terpadu di Taman Kanak-Kanak. Jurnal Pendidikan dan Kebudayaan. Maret 2005 . No 053 Tahun ke 11,h. 177-206

(2003). Pengembangan Kemampuan Koordinasi Motorik Kasar Dan Halus Anak Usia Taman Kanak-Kanak. Jurnal Pendidikan Anak Usia Dini. Vol 1. No 1. Januari h 4061 (2005). Pendidikan Anak Sejak Usia Dini Sebagai Usaha Kongkrit Dalam Mempersiapkan Aset Bangsa di Masa Depan. (Orasi Ilmiah). Jakarta : UNJ

Jamaris, M., Eliza, D., Wuryani., \& Mulyeni Mulyeni. (2012). Profil Kecerdasan Jamak Anak Usia 4-5 Tahun. Jakarta: PPs UNJ

Pohl, M. (2000). Learning to Think and Thinkin to Learning. Australia: Hawker Brownlow Education.

Fograty, R. (1991). How to Integrate Curricula. New York: Colombia University Teachers College

Kuebler, R. R., \& Harry, S. Jr. (1980 ) Statistics. New York : John Wiley \& Sons, Inc.

Wortham, S. C. Measurament and Evaluation in Early Childhood Education. New Jersel: Merril an inprint of Prentice Hall

Ross, V., Marshall, H. M., \& Scott, M. A. (1999). Child Psychology. New York: John Weley \& Sons, Inc 